\title{
A família do p53: aspectos estruturais e funcionais do p73 e do p63
}

\author{
The p53 family: structural and functional aspects of $p 73$ and $p 63$
}

Alfredo Ribeiro-Silva ${ }^{1}$

Sérgio Zucoloto ${ }^{2}$

\begin{tabular}{l|l}
\multicolumn{1}{c|}{ unitermos } & res Um \\
p53 & O p53 é um gene regulador chave do ciclo celular que, quando sofre mutações, leva ao \\
p63 & $\begin{array}{l}\text { desenvolvimento de neoplasias, atuando, portanto, como um gene supressor tumoral em } \\
\text { condições normais. Recentemente foram identificados genes homólogos ao p53 denomina- } \\
\text { dos p73 e p63, provavelmente oriundos de um gene ancestral comum. Apesar da grande } \\
\text { Apoptose }\end{array}$ homologia estrutural, os membros da família do p53 possuem diferenças funcionais entre si. \\
Neoplasias & $\begin{array}{l}\text { O presente artigo tem por finalidade discorrer sobre os principais aspectos estruturais e } \\
\text { funcionais do p73 e do p63, ressaltando seus papéis na tumorigênese humana. O p73 ativa } \\
\text { vários genes responsivos ao p53 e, quando superexpresso, inibe a ação do p53. Raramente } \\
\text { encontra-se mutado em neoplasias, e seu papel na tumorigênese humana ainda é motivo de } \\
\text { controvérsias. O p63 não é um gene supressor tumoral clássico, sendo essencial para a } \\
\text { manutenção de uma população de células precursoras (células-tronco) em vários tecidos } \\
\text { epiteliais. O p63 marca as células basais de vários órgãos epiteliais, como a pele e a próstata, } \\
\text { podendo ser considerado um marcador de indiferenciação celular. O p63 é um marcador } \\
\text { recentemente descrito e ainda requer maior investigação para determinar seu papel no } \\
\text { desenvolvimento de neoplasias em humanos. }\end{array}$
\end{tabular}

abstract key words

The p53 gene has a key role in the cell cycle control. When mutated, it promotes the development of neoplasms, acting in so far as a tumor suppressor gene in normal conditions. Recently, genes homologue to p53 were identified, named p73 e p63, probably originated from a common ancestral gene. Despite the great structural homology, the members of p53 family have functional differences. This article aims to discourse about the major structural and functional aspects of p73 and $p 63$, reinforcing their role in human tumorigenesis. $\mathrm{P73}$ activates several $p 53$ responsive genes and, when overexpressed, inhibits the p53 action. It is rarely mutated in neoplasms and its role in human tumorigenesis is still controversial. P63 is not a classical tumor suppressor gene, being essential for the maintenance of a population of precursor cells (stem cells) in several epithelial tissues. P63 is detectable in the basal cells of several epithelial organs like skin and prostate and could be considered a hallmark of cellular undifferentiation. P63 is a recently p53 p73 p63 Apoptosis Cell cycle Neoplasia described marker and still requires more investigations to determine its role in the development of neoplasms in humans.

\section{Introdução}

O p53 é um gene regulador chave do ciclo celular que, quando sofre mutações, leva ao desenvolvimento de neoplasias, atuando, portanto, como um gene supressor tumoral em condições normais (22). Recentemente foram identificados genes homólogos ao p53 denominados p73 e p63, provavelmente oriundos de um gene ancestral comum $(9,50)$. Estruturalmente, as proteínas codificadas por estes dois genes são similares, mas não idênticas, ao p53. Também compartilham algumas funções, mas o papel fisiológico nas
1. Doutor em Patologia Humana pelo Departamento de Patologia da Faculdade de Medicina de Ribeirão Preto da Universidade de São Paulo (FMRP/USP); médico assistente do Serviço de Patologia do Hospital das Clínicas de Ribeirão Preto (HCFMRP/USP). 2. Doutor em Patologia; professor titular do Departamento de Patologia da FMRP/USP. 
células parece ser diferente (64). O presente artigo tem por finalidade discorrer sobre os principais aspectos estruturais e funcionais do p73 e do p63, ressaltando seus papéis na tumorigênese humana.

\section{p73: estrutura, função e papel nas neoplasias}

Entre os membros da família do p53, o p73 foi o primeiro gene identificado. Codifica uma proteína bastante similar à proteína supressora tumoral do p53 (27). Existem pelo menos seis proteínas oriundas do gene p73 que foram identificadas com letras gregas de $\alpha$ a $\zeta$. Estas proteínas são formadas por emendas alternativas na extremidade $3^{\prime}$ do p73 de células normais. As isoformas $\beta$ e $\delta$ são formas truncadas (respectivamente nos aminoácidos 399 e 494) do comprimento total da isoforma $\alpha$ do $p 73$. Na isoforma $\zeta$ faltam os aminoácidos 400 a 496 da isoforma $\alpha$, mas mantém a porção remanescente carboxiterminal. A isoforma $\gamma$ contém um longo molde alternativo de leitura e, conseqüentemente, possui uma porção C-terminal completamente diferente. A isoforma $\varepsilon$ compartilha regiões das isoformas $\gamma$ e $\alpha(8,58)$. Recentemente foi identificada uma nova isoforma do $p 73$, que foi denominada Delta Np73 (25).

Camundongos deficientes em p73 têm todas as isoformas deletadas e apresentam taxas de apoptose aumentadas, sugerindo que em condições normais o p73 tem uma atividade antiapoptose, contrapondo-se ao efeito pró-apoptose do p53 (42). Entretanto, de maneira similar ao p53, o p73 pode bloquear o ciclo celular e desencadear apoptose quando está superexpresso (49). De fato, o p73 é necessário para desencadear o mecanismo de apoptose dependente do p53 em resposta à lesão no DNA (17). Entretanto existem evidências de que danos ao DNA possam induzir a acetilação do p73 através da acetiltransferase p300, causando apoptose por um mecanismo independente do p53 (7) (Figura 1).

Não existe um consenso acerca do papel do p73 nos tumores malignos. Vários autores não conseguiram identificar nenhuma mutação somática do p73 em tumores sólidos, argüindo contra um papel significativo deste gene na patogênese do câncer em humanos $(21,30,33,36$, $37,44,46,53,56,66)$.

O p73 foi mapeado no cromossomo 1p36, uma região em que a perda da heterozigosidade é freqüentemente observada em tumores humanos (2). A perda de alelos no braço $1 p$ é observada em $13 \%$ a $75 \%$ dos carcinomas mamários, conforme o intervalo gênico estudado. Tumores com essas perdas apresentam pior prognóstico, apresentando alto grau histológico, invasão angiolinfática peritumoral e ausência de receptores hormonais (13). De fato, a perda da heterozigosidade do p73 foi verificada em carcinomas mamários de mau prognóstico $(1,13)$.

Existem evidências de que o $p 73$ possa ser expresso por apenas um alelo e de que a perda desta única cópia seria suficiente para que o gene perdesse sua função, com o conseqüente desenvolvimento do câncer (27). Entretanto, estudos mostraram que é rara a expressão de apenas um alelo deste gene $(36,66)$.

A expressão de variantes mutadas do p73 aparentemente desempenha um papel importante na patogênese do câncer de ovário, sendo detectado em $50 \%$ dos tumores ovarianos invasores (35). Além disso, verificou-se que o p73 tem participação importante na carcinogênese dos tumores escamosos da cabeça e do pescoço $(6,16,62)$.

Como o p73 é um gene bastante homólogo ao p53 e encontra-se deletado em neuroblastomas, a idéia inicial é de que também fosse um gene supressor tumoral (27). Entretanto estudos de mutação realizados em grande nú-

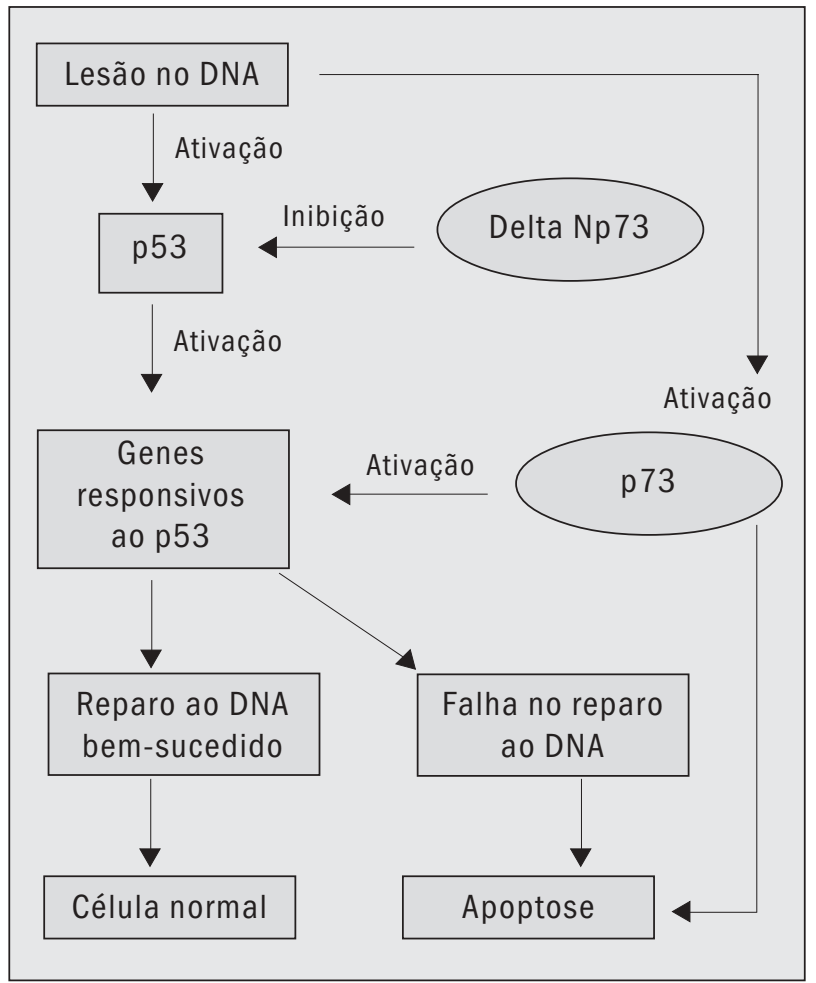

Figura 1 - 0 produto do gene p73 é capaz de ativar genes responsivos ao p53 (p21 MDM2, ciclina-G, GADD45 e bax, entre outros), promovendo apoptose e bloqueio do ciclo celular. 0 p73 também é capaz de induzir apoptose através de um mecanismo independente do p53. A isoforma Delta N p73, freqüentemente superexpressa em neoplasias, inibe o p53, atuando indiretamente como um oncogene 
mero de diferentes tumores humanos detectaram apenas três mutações aparentemente sem significado. Os raros trabalhos com o p73 também identificaram três mutações, aparentemente sem importância prática $(39,52)$. Vários tumores expressam altos níveis de p73 quando comparados com o tecido normal que os origina, sugerindo que, na realidade, possa ocorrer uma expressão alterada do p73, e não a perda de sua função, como ocorre com o p53 (14, $30,54,55)$.

A superexpressão do p73 em meningeomas, neuroblastomas e adenocarcinomas colorretais acarreta pior prognóstico, sendo que a expressão do p73 aumenta proporcionalmente ao grau tumoral. Entretanto não foram detectadas mutações no gene do p73 nestas neoplasias (4, $37,51)$. Recentemente identificou-se uma nova isoforma do gene p73, denominada Delta Np73, com efeito inibitório sobre o gene p53 (25). Portanto, apesar de raramente mutado, o p73 pode atuar indiretamente como um oncogene quando superexpresso, por inibir o p53.

\section{p63: estrutura, função e papel nas neoplasias}

O p63 também é um gene análogo ao p53, identificado no lócus $3 q 27-9(39,45,57)$. O gene p63 possui pelo menos seis isotipos. Observa-se uma isoforma $\alpha$ íntegra, uma isoforma $\beta$ truncada e uma isoforma $\gamma$ sem os éxons de 11 a 14 e com um éxon 15 adicional não encontrado no p73. Estes isotipos (TAp63 $\alpha$, TAp63 $\beta$ e TAp63 $\gamma$ ) possuem a habilidade de ativar o gene p53 e, com isso, induzir apoptose e bloquear o ciclo celular (12). Entretanto os outros três isotipos ( $\Delta N p 63 \alpha, \Delta N p 63 \beta$ e $\Delta N p 63 \gamma)$, transcritos de um promotor interno localizado no íntron 3 , agem como dominante negativo à ação supressora tanto do p53 quanto dos isotipos TAp63 (64) (Figura 2). A isoforma delta do p63 não compartilha de muitos dos domínios de ligação do p53 (29). Portanto, apesar da homologia estrutural, não existem evidências de que o p63 seja um gene supressor tumoral como o p53 (31). O p63 também pode desempenhar um papel na senescência replicativa por competir com sítios de ligação do p53 ao DNA ou por uma interação direta com proteínas do p53 ligadas ao DNA (11).

Camundongos deficientes em p63 exibem diversos defeitos no desenvolvimento de órgãos epiteliais, de membros e de estruturas craniofaciais, falecendo logo após o nascimento. Apresentam membros malformados e truncados e não apresentam folículos pilosos, dentes, próstata e glândulas mamárias, lacrimais e salivares $(34,65)$. Estes trabalhos sugerem que o p63 seja essencial para a manutenção de uma população de células precursoras (células tronco) em vários tecidos epiteliais. Em humanos, defeitos similares são verificados em síndromes congênitas caracterizadas por ectrodactilia, displasia ectodérmica e fendas faciais (5). Recentemente foi demonstrado que estas síndromes são causadas por mutações no p63 (15, $48,59,60)$.

O p63 é seletivamente expresso no compartimento basal de vários tecidos epiteliais como os epitélios escamoso, mamário, salivar, prostático e de glândulas lacrimais, e pode ser considerado um marcador de células de reserva (células-tronco) destes tecidos $(3,40,41,47,61)$. No endométrio o p63 marca apenas as células basais do tecido fetal, desaparecendo durante a fase reprodutiva. Estes dados reforçam o papel do p63 como um marcador de células indiferenciadas multipotenciais (38). No esôfago normal o p63 é expresso nas camadas basal e suprabasal do epitélio escamoso e nas células basais que circundam os ductos das glândulas mucosas, sendo negativo em todos os outros tecidos epiteliais do trato gastrointestinal, incluindo o estômago, o intestino delgado e o cólon (19).

O p63 foi mapeado no cromossomo 3q27-29, uma região que se encontra alterada nas neoplasias de pulmão, colo uterino e ovário $(23,24)$. Entretanto, assim como no

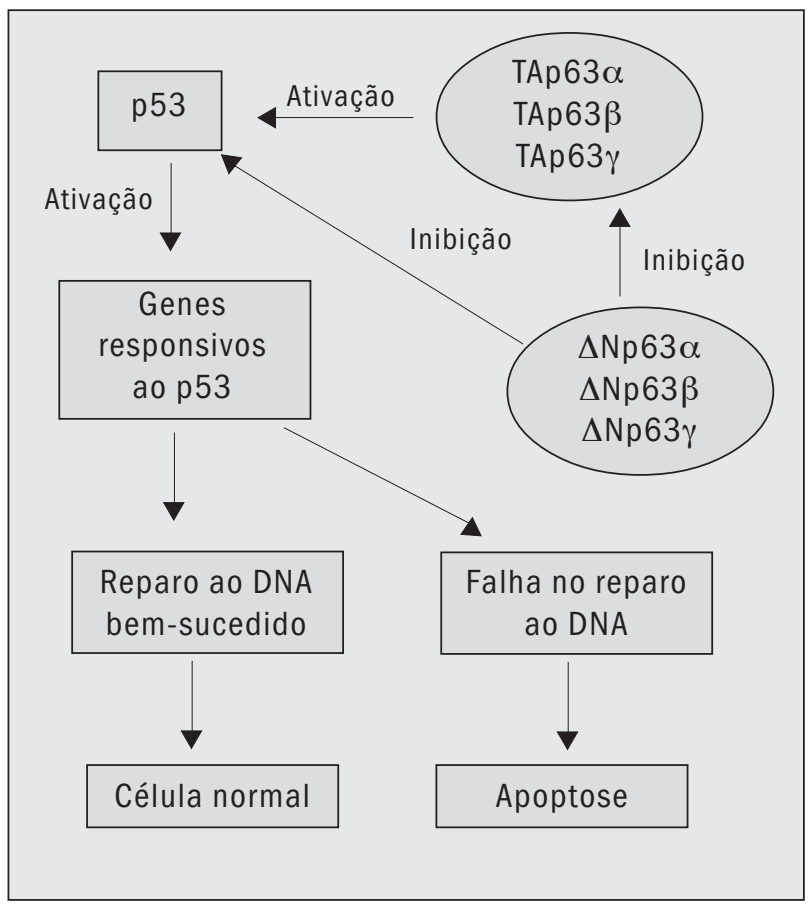

Figura 2 - As isoformas TAp63 $\alpha$, TAp63 $\beta$ e TAp63 $\gamma$ do gene p63 são capazes de ativar 0 gene $p 53$. Entretanto as isoformas $\Delta N p 63 \alpha, \Delta N p 63 \beta$ e $\Delta N p 63 \gamma$ agem como dominante negativo à ação tanto do p53 quanto dos isótopos TAp63. Portanto 0 gene p63 aparentemente não é um supressor tumoral como o seu homólogo p53 
p73, mutações no p63 são raras e seu papel na tumorigênese ainda necessita ser mais bem explorado. Mutações no p63 geralmente ocorrem entre os códons 151170 e estão associadas a crise blástica na leucemia mielóide crônica (63).

O p63 encontra-se superexpresso no carcinoma epidermóide do esôfago, mas não nos adenocarcinomas colorretal e esofágico, sugerindo que o p63 possa contribuir para a carcinogênese dos tumores escamosos (19). Além disso, verificou-se correlação entre expressão do p63 e mutação no p53 em neoplasias avançadas e displasias de alto grau esofágicas (20).

No trato genital feminino inferior o p63 marca as células escamosas maduras e neoplásicas, podendo ser utilizado como um marcador de diferenciação escamosa em tumores pouco diferenciados $(43,61)$. O p63 não é expresso em carcinomas endometriais, mas está fortemente associado a metaplasia escamosa do tecido endometrial (38). Estes dados sugerem que o $\mathrm{p} 63$ possa ser um indicador de diferenciação escamosa. Em carcinomas metastáticos pouco diferenciados de sítio primário desconhecido, a co-expressão do p63 com as citoceratinas 5 e 6 favorece, como tecido de origem do tumor, o epitélio escamoso (28). De fato, o p63 está mais associado a carcinomas escamosos e de células transicionais do que a adenocarcinomas (10).

Na próstata, o p63 marca as células basais no tecido normal, na hiperplasia prostática e nas neoplasias intraepiteliais de baixo e alto graus. Nos carcinomas, sua expressão só é verificada em $6 \%$ dos espécimes provenientes de prostatectomia radical, mas correlacionase fortemente com neoplasias de alto grau (41). Não foram detectadas mutações do p63 no carcinoma gástrico, embora o número de células positivas para o p63 seja inversamente proporcional ao grau de diferenciação tumoral (56). O p63 encontra-se superexpresso em $68,2 \%$ dos casos de adenocarcinoma pancreático, e não se correlaciona com a expressão do p53 (26).

Tumores humanos derivados de mutações no p53 (p53His175 e p53Gly281) estão associados com as isoformas alfa, beta, gama e delta do p73. Esta associação reduz de maneira significativa a capacidade de transcrição normal destas isoformas (49). Além disso, os tumores derivados de mutações no $p 53$ também inibem a expressão das isoformas alfa, gama e delta do p63 (18). Esta inibição do p73 e do p63 pelo p53 pode favorecer a tumorigênese $(18,49)$.

\section{Conclusões}

Os dados disponíveis até o momento sugerem que, apesar de possuírem características estruturais similares, os membros da família p53 compartilham menos funções entre si do que seria esperado. Enquanto o p53 possui como principal função responder às agressões ao DNA, 0 p63 parece ser essencial ao desenvolvimento e diferenciação de determinados tecidos. Portanto, o produto do gene p63 aparentemente não é um supressor tumoral como o p53 (32). O P73 possui as duas funções, participando da diferenciação de tecidos e da resposta ao dano do DNA, por mecanismo paralelo e independente ao do p53 (9).

\section{Referências}

1. A ho madegbe, J.C . et al. Loss of heterozygosity, allele silencing and decreased expression of p73 gene in breast cancers: prevalence of alterations in inflammatory breast cancers. Oncogene, 19: 5413-18, 2000.

2. Araki, D. et al. Frequent allelic losses on the short arm of chromosome 1 and decreased expression of the p 73 gene at $1 p 36.3$ in squamous carcinoma of the oral cavity. Int. J. Oncol., 20: 355-60, 2002.

3. Barbareschi, M. et al. P63, a p53 ho mologue, is a selective nuclear marker of myoepithelial cells of the human breast. Am.J. Surg. Pathol., 25: 1054-60, 2001.

4.C asciano, I. et al. Expression of D eltaN p73 is a molecular marker for adverse outcome in neuroblastoma patients. Cell Death Differ., 9: 246-51, 2002.

5. Celli, J. et al. Heterozygous germline mutations in the $p 53$ homolog p63 are the cause of EEC syndrome. Cell, 99 : 143-53, 1999.
6. Choi, H.R. et al. Differential expression of p53 gene family members p63 and p73 in head and neck squamous tumorigenesis. Hum. Pathol., 33: 158-64, 2002.

7. Costanzo,A et al. D N A damage-dependent acetylation of p73 dictates the selective activation of apoptotic target genes. Mol. Cell, 9: 175-86, 2002.

8. De Laurenzi, V. et al. Additional complexity in p73: induction by mito gens in lymphoid cells and identification of two new spicing variants epsilon and zeta. Cell Death Differ., 6:389-90, 1999.

9. De Laurenzi,V. \& Melino, G. Evolution of functions within the p53/p63/p73 family. Ann. N.Y. Acad. Sci., 926:90-100, 2000.

10. Di Como, C J. et al. P63 expression profiles in human normal and tumor tissues. Clin. Cancer Res., 8: 494-501, 2002.

11. D jelloul, S. et al. D ifferential protein expression, D N A binding and interaction with SV 40 large tumour antigen implicate the p63-family of proteins in replicative senescence. Oncogene, 21:981-89, 2002. 
12. D ohn, M.; Zhang, S. \& Chen, X. P63alpha and deltaN p63alpha can induce cell cycle arrest and apoptosis and differentially regulate p53 target genes. Oncogene, 20:3193-205, 2001.

13. D omínguez, G et al. C linico patholo gical characteristics of breast carcinomas with allelic loss in the $\mathrm{p} 73$ region. Breast Cancer Res.Treat., 63: 17-22, 2000.

14. Douc-Rasy, S. et al. DeltaN -p73alpha accumulates in human neuro blastic tumors. Am. J. Pathol., 160:631-39, 2002.

15. D uijf, P.H . et al. Gain-of-function mutation in A dult syndrome reveals the presence of a second transactivation domain in p63. Hum. Mol. Genet., 11: 799-804, 2002.

16. Faridoni-Laurens, L. et al. P73 expression in basal layers of head and neck squamous epithelium: a role in differentiation and carcinogenesis in concert with p53 and p63. Oncogene, 20: 5302-12, 2001.

17. Flores, E.R. et al.P63 and p73 are required for p53-dependent apoptosis in response to DN A damage. Nature, 416:560$64,2002$.

18. Gaiddon, C .et al.A subset of tumor-derived mutant forms of p53 down-regulate $p 63$ and $p 73$ through a direct interaction with the p53 core domain. Mol. Cell. Biol., 21: 1874-87, 2001.

19. G lickman, J.N . et al. Expression of p53-related protein p63 in the gastrointestinal tract and in esophageal metaplastic and neo plastic disorders. Hum. Pathol., 32: 1157-65, 2001.

20. Hall, P.A . et al. Expression of the p53 ho mologue p63alpha and D eltaN p63alpha in the neoplastic sequence of Barrett's oeso phagus:correlation with morphology and p53 protein. Gut, 49:618-23, 2001.

21. $\mathrm{H}$ an, S. et al. Infrequent somatic mutations of the $\mathrm{p} 73$ gene in various human cancers. Eur.J. Surg. Oncol., 25:194-98,1999.

22. Hollstein, M. et al. P53 mutations in human cancers. Science, 253:49, 1991.

23. Irwin, M.S. \& Kaelin Jr,W .G.P53 family update: p73 and p63 develop their own identities. Cell. Growth Differ., 12: 33749, 2001.

24. Irwin, M.S.\& Kaelin Jr,W .G . Role of the newer p53 family proteins in malignancy. Apoptosis, 6:17-29, 2001.

25. Ishimoto, 0 . et al. Possible oncogenic potential of D eltaN p73: a newly identified isoform of human $p 73$. Cancer Res., 62 : 636-41, 2002.

26. Ito,Y. et al. Expression of p73 and p63 proteins in pancreatic adenocarcinoma:p73 overexpression is inversely correlated with biolo gical aggressiveness. Int.J. M ol. M ed., 8:67-71, 2001.

27. Kaghad, $M$. et al. Monoallelically expressed gene related to p53 at 1p36, a region frequently deleted in neuroblasto ma and other human cancers. Cell, 90:809-19, 1997.

28. Kaufmann, 0 . et al. Value of p63 and cytokeratin $5 / 6$ as immunohistochemical markers for the differential diagnosis of poorly differentiated and undifferentiated carcinomas. Am. J. Clin. Pathol., 116: 823-30, 2001.

29. Klein, C . et al. High thermostability and lack of cooperative DNA binding distinguish the p63 core domain from the homologous tumor suppressor p53. J. Biol. Chem., 276: 37390-401, 2001.

30. Kovalev, S. et al. Expression level, allelic origin, and mutation analysis of the $p 73$ gene in neuroblastoma tumors and cell lines. Cell. Growth Differ., 9:897-903, 1998.
31. Levrero, M. et al. Structure, function and regulation of $p 63$ and p73. Cell. Death Differ., 6: 1146-53, 1999.

32. Little, N .A.\& Jochemsen, A.G . P63. Int. J. Biochem. Cell. Biol., 34: 6-9, 2002.

33. Mai, M .et al.A ctivation of $\mathrm{p73}$ silent allele in lung cancer.Cancer Res., 58: 2347-49, 1998.

34. Mills, A.A. et al. P63 is a p53 homologue required for $\operatorname{limb}$ and epidermal morphogenesis. N ature, 398: 708-13, 1999.

35. $\mathrm{N} \mathrm{g}$, S-W . et al.A nalysis of p73 in human bo rderline and invasive ovarian tumor. Oncogene, 19:1885-90, 2000.

36. N omoto, S. et al. Search for mutations and examination of allelic expression imbalance of the p73 gene at 1p36.33 in human lung cancers. Cancer Res., 58: 1380-83, 1998.

37. N ozaki, M. et al. P73 is not mutated in meningiomas as determined with a functional yeast assay but $p 73$ expression increases with tumor grade. Brain Pathol., 11: 296-305, 2001.

38. 0 'C onnell, J.T. et al. Identification of a basal/reserve cell immunophenotype in benign and neoplastic endometrium: a study with the p53 homologue p63. Gynecol. Oncol., 80: 30-6, 2001.

39. 0 sada, M. et al. C loning and functional analysis of human p51, which structurally and functionally resembles p53. Nat. M ed., 4:839-43, 1998.

40. Parsa, R. et al.Association of p63 with pro liferative potential in normal and neoplastic human keratinocytes. J. Invest. Dermatol., 113: 1099-105, 1999.

41. Parsons, J.K. et al. P63 protein expression is rare in prostate adenocarcinoma: implications for cancer diagnosis and carcinogenesis. Urology, 58: 619-24, 2001.

42. Pozniak, C.D. et al.An anti-apoptotic role for the p53 family member, p73, during develo pmental neuron death. Science, 289: 304-6, 2000.

43. Q uade,B.J. et al. Expression of the p53 in early cervical neo plasia. Gynecol. Oncol., 80:24-9, 2001.

44.Schwartz, D.I. et al. P73 mutations are not detected in sporadic and hereditary breast cancer. Breast Cancer Res.Treat., 58: 25-9, 1999.

45. Senoo, M. et al.A second p53-related protein, p73L, with high homology to p73. Biophys. Res.Commun., 248:603-07,1998.

46. Shishikura,T. et al. Mutational analysis of the $p 73$ gene in human breast cancers. Int. J. Cancer, 84: 321-5, 1999.

47. Signoretti, S. et al. P63 is a prostate basal cell marker and is required for prostate development. Am.J.Pathol., 157:1769$75,2000$.

48.South,A.P.et al.EEC (ectrodactyly,ecto dermal dysplasia, clefting) syndrome:heterozygo us mutation in the p63 gene (R279H) and DNA-based prenatal diagnosis. Br. J. Dermatol., 146: 216-20, 2002.

49. Strano, S. et al. Physical and functional interaction between p53 mutants and different iso forms of p73. J. Biol. Chem. 275: 29503-12, 2000.

50. Strano, S. et al. From p63 to p53 across p73. FEBS Lett., 490: 163-70, 2001.

51. Sun, X .F. P73 overexpression is a prognostic factor in patients with colorectal adeno carcinoma. Clin. Cancer Res., 8: 16570, 2002. 
52. Sunahara, M et al. M utational analysis of the $p 73$ gene localized at chromo some 1 p36.3 in colorectal carcino mas. Int.J. Oncol,, 13: 319-23, 1998.

53. Takahashi, H. et al. Search for mutations and examination of allelic expression imbalance of $p 73$ gene at $1 p 36.33$ in human lung cancers. Cancer Res., 58:2076-7, 1998.

54.Tannapfel,A .et al. Expression of $\mathrm{p} 73$, a novel protein related to the p53 tumor suppressor p53 and apoptosis in cholangio cellular carcinoma of the liver. Br. J. Cancer, 80: 1069-74, 1999.

55. Tannapfel, A. et al. Expression of $p 73$ and its relation to histopathology and progno sis in hepatocellular carcinoma. J. Natl. Cancer Inst., 91: 1154-8, 1999.

56.Tannapfel,A et al. Expression of the p53 homologues p63 and p73 in multiple simultaneous gastric cancer. J. Pathol., 195: 163-70, 2001.

57.Trink, B. et al.A new human p53 homologue. Nat. Med., 4:747-8, 1998.

58. U eda, Y. et al. N ew p73 variants with altered C-terminal structures have varied transcriptional activities. Oncogene, 18: 4993-8, 1999.

59.Van Bokhoven, H . et al. P63 gene mutations in eec syndrome, limb-mammary syndrome, and isolated split hand/split foot malformation suggest a genotype/phenotype correlation. Am. J. H um. Genet., 69: 481-92, 2001.

60. Van Bo khoven, H.\& McKeon, F. Mutations in the p53 homolog p63: allele-specific developmental syndrome in humans. Trends Mol. Med., 8: 133-9, 2002.

61. W ang,T.Y. et al. Histologic and immunophenotypic classification of cervical carcinomas by expression of the p53 homologue p63: a study of 250 cases. Hum. Pathol., 32: 479-86, 2001.

62. Weber, A. et al. Expression of p53 and its homologues in primary and recurrent squamous cell carcinomas of the head and neck. Int. J. Cancer, 99:22-8, 2002.

63. Yamaguchi, H. et al.Mutation of the $p 51 / p 63$ gene is associated with blastic crisis in chronic myelogenous leukemia. Leukemia, 15: 1729-34, 2001.

64. Yang,A . et al. P63, a p53 homolog at 3q27-29, encodes multiple products with transactivating, death-inducing, and dominant-negative activities. Mol. Cell., 2: 305-16, 1998.

65.Yang, A . et al. P63 is essential for regenerative proliferation in limb, craniofacial and epithelial development. Nature, 398: 714-8, 1999.

66. Zaika, A.I. et al. 0 verexpression of the wild type p73 gene in breast cancer tissues and cell lines. Cancer Res., 59:3257$63,1999$. 